\title{
Chikungunya infection in infants
}

\author{
Maria do Carmo Menezes Bezerra Duarte 1 \\ Arino Faria de Oliveira Neto 2 \\ Patrícia Gomes de Matos Bezerra 3 \\ Lara Alves Cavalcanti 4 \\ Vanessa Máximo de Brito Silva 5 \\ Suelda Grasiela Alves Araújo de Abreu 6 \\ Susana Farias Batista Leite 7 \\ Nara Vasconcelos Cavalcanti 8
}

1-8 Instituto de Medicina Integral Prof. Fernando Figueira (IMIP). Rua dos Coelhos, 300. Recife, PE, Brasil. CEP: 50.070-550.

E-mail: mcduarte2010@gmail.com

\begin{abstract}
Introduction: the infection of chikungunya virus presents clinical manifestations variables, particularly in infants in which may present multiple cutaneous manifestations.

Description: a case series study was carried out in an analytical character of 14 infants (>28 days to $<2$ years old) admitted in a hospital between November 2015 and January 2016 with suspected case of chikungunya, by a specific IgM reactive serology. Patients positive for dengue fever, Zika virus, bacterial infections and other exanthematic diseases were excluded. Fever and cutaneous alterations were the most frequent clinical manifestations in $100 \%$ of the cases, followed by irritability (64.3\%), vomits and arthralgia/arthritis in $35.7 \%$ each. Three children presented alterations in the cerebrospinal fluid compatible to meningitis. Anemia frequency was $85.7 \%$. The median white blood cells count was $7.700 / \mathrm{mm}^{3}$ (2.600 to $20.300 / \mathrm{mm}^{3}$ ). High levels of aminotransferases were observed in three cases (230 to 450 $U / L)$. Antibiotic therapy was indicated in $64.3 \%$ of the cases. Two infants needed opioid derivatives for analgesia while others took acetaminophen and/or dipyrone.

Discussion: the study shows evident multi-systemic involvement of chikungunya infection in infants. The treatment is supportive, giving special attention to hydration, analgesia, skin care, and rational use of antibiotic therapy.
\end{abstract}

Key words Chikungunya, Cutaneous manifestations, Infants 


\section{Introduction}

Chikungunya is a arbovirus caused by chikungunya virus (CHIKV) of the simple RNA chain, Alphavirus gender, Togaviridae classification and is transmitted to humans by the main vectors identified as the Aedes aegypti and Aedes albopictus mosquito's bite. The outbreak around the world mainly is due to the mosquito's adaptation in colder climates, expanding its geographic distribution, in addition to the genetic adaptations of the virus, which led to an increase of its infectivity and dissemination. 1,2

Between the years 1950 and 2000, CHIKV caused many foci of infection, especially in Africa, Asia and Pacific regions. ${ }^{2}$ In December 2013, chikungunya infection was first reported in the Americas, in Saint Martin, the Caribbean. ${ }^{3}$ In Brazil, the first autochthonous case of the disease was confirmed in 2014.4 In 2016, 64.349 cases of chikungunya were reported up to the 16 Epidemiological week (Jan. 3, 2016 to April 23, 2016), of those 64.349 cases, 11.182 were confirmed.5

The horizontal transmission of chikungunya infection occurs in children and adults through the vector mosquito's bite. The incubation period does not differ with age, but this period is an average of 2-7 days (ranging from 1-12 days).2,6 The clinical manifestations varies and comprehends the asymptomatic or oligosymptomatic forms up to a more severe disease and potentially fatal. 7 The clinical presentation of the disease differs among infants, older children and adults, regarding the magnitude of the symptoms and its diversity, it seems to describe a curve in the form of "U", which occurs in maximum in young infants and in elderly and in minimum in older children and adults. ${ }^{8}$

There are few studies in medical literature that describe the clinical, laboratorial and therapeutic findings by chikungunya infection in the pediatric population, especially in infants and in the American continent. There seems to be a multiplicity of cutaneous manifestations with vesicles, blisters and hyperpigmented lesions in infants less than six months of age. Therefore, the objective of this study was to describe and analyze clinical, laboratorial and therapeutic characteristics for hospitalized infants with chikungunya infection.

\section{Description}

This is a case series study in an analytical character performed through the identification of cases reported suspected of being chikungunya infection at the Epidemiology Nucleus at the Instituto de Medicina Integral Prof. Fernando Figueira (IMIP) during the period of November 30, 2015 to January 17, 2016 (49 days). IMIP is a referral teaching hospital in the Northeast of Brazil which attends exclusively patients of the Unified Health System (SUS)

Infants ( $>28$ days to $<2$ years) admitted at IMIP suspected of chikungunya infection by specific laboratorial confirmation were included. The IgM antiCHIKV serology reagent was performed by immunoenzymatic assay (ELISA) using MACELISA kit (CDC/Atlanta/USA), according to the manufacturer's instructions. The definition of a suspected case of chikungunya infection was adopted by infants with fever reported by their parents by a sudden unexplained onset with other conditions and exanthema, residing or have visited endemic or epidemic areas of CHIKV until two weeks before the onset of the symptoms. Patients who presented positive laboratorial test for alternative diagnosis such as: dengue, Zika virus, bacterial infection and other exanthematic diseases were excluded.

The information was collected from the patients' medical records in the Medical Files and Statistics Service at IMIP according to the eligibility criteria. The evaluated variables were gender, age, weight, origin, clinical manifestations, including cutaneous, osteoarticular and neurological, peripheral cyanosis, duration of fever, comorbidities, length of hospital stay, laboratory characteristics and therapeutic measurements used (type of venous access, volume expansion, antibiotic therapy, analgesia, skin care and blood transfusion).

The data were typed and analyzed in a database built in Microsoft Excel ${ }^{\circledR} 2013$ program. In the descriptive analysis of the data, the categorical variables are presented in the text as absolute frequencies and/or relating to, while the numerical variables are through the central tendency and dispersion measurements. The tables present individual descriptive results. The study was approved by the Human Research Ethics Committee at IMIP (Document number: CAAE: 57076616.2.0000.520).

The clinical characteristics of the 14 infants evaluated are shown in Table 1. The median (amplitude) of age was two months (one to 19 months) and the male gender was the most frequent $(64.3 \%)$. The median (amplitude) duration of the fever was four days (one to 16 days). The most clinical manifestations were fever and cutaneous alterations in $100 \%$ of the cases, followed by irritability $(64.3 \%)$, vomiting and arthralgia/arthritis in $35.7 \%$ each. Three children had abnormal cerebrospinal fluid 
compatible to meningitis and a three months old infant had seizures.

In relation to cutaneous manifestations, all cases presented macular exanthema diffuse beginning at the lower limbs and trunk in nine cases, interspersed in areas of hyperpigmentation and sometimes in hypochromic areas (pale) well defined (Figure 1). Four infants, between one to two months of age, presented flaccid blisters and clear content that broke out spontaneously and evolved in crusts (duration of three to five days). There was no description of mucous membranes involvement and three cases presented secondary infection (N 3, 11 and 12). The median (amplitude) time of hospital stay was eight (4 to 18) days and there were no deaths (Table 1).

As for laboratorial characteristics (Table 2), the frequency of anemia9 considering the cut-off point of hemoglobin $(\mathrm{Hb})<11.5 \mathrm{~g} \%$ was $85.7 \%$, and $\mathrm{Hb}$ $<9.5 \mathrm{~g} \%$ of $57.1 \%$, with an amplitude of 6.3 to 12.2 $\mathrm{g} \%$. The median (amplitude) of white blood cells count was $7,700 / \mathrm{mm}^{3}$ (2,600 to $\left.20,300 / \mathrm{mm}^{3}\right)$, while six $(43 \%)$ cases showed more than $10 \%$ of immature neutrophils. 10 Two infants presented to have thrombocytopenia $\left(<150.000 / \mathrm{mm}^{3}\right)$. Elevated levels of aminotransferases, especially the aspartate aminotransferase (AST), were observed in three cases (230 to $450 \mathrm{U} / \mathrm{L})$ and in one case of creatine phosphokinase $(\mathrm{CPK})$ was very high $(2,675 \mathrm{U} / \mathrm{L})$. The four children who collect cerebrospinal fluid (LCR), three presented cellularity between 50 to 100 cells $/ \mathrm{mm}^{3}$, with lymphocytes representing $100 \%$, $51 \%$ and $35 \%$ of the total cells.

The therapeutic characteristics of 14 infants evaluated are shown in Table 3. A patient was admitted to the Pediatric Intensive Care Unit (UTIP) and was required an invasive mechanical ventilation for 24 hours. All children received hydration for peripheral venous access, while three of them also needed central venous access. Volume expansion at admission was performed in four $(28.6 \%)$ cases with $0.9 \%$ saline solution (SF) of 20 to $50 \mathrm{ml} / \mathrm{kg} /$ hour. None of the patients needed to take vasoactive drugs. Antibiotic therapy was indicated for $64.3 \%$ of the cases, which $77.8 \%$ were infants less than three months old. Two infants needed opioid derived for analgesia, while others took paracetamol and/or dipyrone. The four infants who presented blisters were treated with topical silver sulfadiazine after cleansing with $0.9 \%$ SF while those with exanthema used vegetable oil with medium-chain triglycerides (TCM).

\section{Discussion}

This case series describes clinical, laboratorial and therapeutic characteristics of a specific age (infants) group hospitalized with laboratorial diagnosis confirmed for Chikungunya infection. This present study describes the first documented cases in Brazil of infants with atypical and severe manifestations caused by CHIKV in the period of November 2015 to January 2016. The infection by CHIKV has reemerged as a public health problem in both tropical and temperate climate countries. ${ }^{1}$ Study reports that in endemic or epidemics areas of Chikungunya infection, such virus should be taken in consideration of differential diagnosis of small children with cutaneous manifestation of feverish bullous. 11

Unlike the clinical manifestations observed in older children and adults, chikungunya infection in infants seems to be quite specific and represents a high-risk group of atypical and/or severe manifestations. These findings include vesiculobullous cutaneous manifestations and ulcers, neurological complications, increased aminotransferases and among other. $8,11-17$ A prospective study in Surinam in the period of June 2014 to April 2015 evaluated 180 suspected cases of CHIKV, aged between two and 82 years and did not find any case of bullous lesions. 18 Furthermore, a multicenter study in India in the period of June 2009 to May 2010, verified significant differences in clinical manifestations (exanthema, headache, arthralgia/arthritis, vomiting and irritability) among children aged eight to 18 years, when comparing infants under the age of eight. 19

The clinical findings of this present study were fever and cutaneous manifestations (in all cases), followed by irritability, arthralgias/arthritis and vomiting, while the laboratorial tests had high frequency of anemia, alterations in the leukogram, increased cellularity in LCR and the aminotransferases. The involvement of the multisystemic chikungunya infection in infants, with predominance of the cutaneous tissue whose pathogenesis is still not well understood.

As for clinical manifestations, all infants presented macular exanthema diffuse mostly in the beginning of the lower limbs and chest, and four cases of bullous lesions without reporting ulcers. A study conducted on the island of La Réunion, in the period of March 2005 to October 2006, evaluated 13 cases of severe bullous cutaneous manifestations in infants less than six months old, also without reports of ulcerations. 11 Another study conducted in India, during an outbreak in 2009-2010 on cutaneous mani- 
Clinical characteristics of 14 infants with chikungunya, 11/30/2015 to 01/17/2016.

\begin{tabular}{|c|c|c|c|c|c|c|}
\hline $\begin{array}{l}\text { Patient } \\
\text { Number/ } \\
\text { Gender }\end{array}$ & $\begin{array}{l}\text { Age (bm )/ } \\
\text { Weight (Kg) }\end{array}$ & $\begin{array}{l}\text { Clinical manifestations, as well } \\
\text { as fever and cutaneous } \\
\text { alterations }\end{array}$ & $\begin{array}{l}\text { Duration } \\
\text { of fever } \\
\text { (days) }\end{array}$ & $\begin{array}{l}\text { Cutaneous manifestations/ Place } \\
\text { of onset and progression }\end{array}$ & Comorbidity & $\begin{array}{l}\text { Length of } \\
\text { hospital stay } \\
\text { (days) }\end{array}$ \\
\hline $1 / \mathrm{F}$ & $3 / 8.1$ & $\begin{array}{l}\text { Vomiting, seizures, irritability, } \\
\text { arthralgia/arthritis }\end{array}$ & 3 & Exanthema begin on the chest & No & 4 \\
\hline $2 / \mathrm{M}$ & $1 / 5.7$ & $\begin{array}{l}\text { Vomiting, irritability, cough, } \\
\text { dyspnea }\end{array}$ & 7 & $\begin{array}{l}\text { Exanthema begin at the MMIlc and } \\
\text { trunk, blisters ( } 3 \text { days ago) evolution } \\
\text { of crusts }\end{array}$ & No & 5 \\
\hline $3 / F$ & $8 / 7.8$ & Cough, dyspnea & 8 & $\begin{array}{l}\text { Exanthema begin at the MMII, } \\
\text { centrifugal }\end{array}$ & Infant wheezing & 5 \\
\hline $4 / \mathrm{M}$ & $1 / 5.3$ & Irritability & 6 & $\begin{array}{l}\text { Exanthema begin on the feet, } \\
\text { centripetal, blisters ( } 4 \text { days), peeling }\end{array}$ & No & 7 \\
\hline $5 / \mathrm{M}$ & $19 / 11.4$ & Irritability, arthralgia/arthritis & 2 & Exanthema begin on the trunk, diffuse & Sickle cell anemia & 9 \\
\hline $6 / \mathrm{M}$ & $2 / 4$ & Edema, irritability & 3 & Exanthema & No & 14 \\
\hline $7 / \mathrm{F}$ & $5 / 6.7$ & Edema, irritability & 7 & Exanthema begin at MMII & No & 6 \\
\hline $8 / \mathrm{M}$ & $2 / 5.5$ & Vomiting, diarrhea, drowsiness & 1 & $\begin{array}{l}\text { Exanthema, begin on the face and } \\
\text { trunk with crust progression }\end{array}$ & No & 10 \\
\hline $9 / \mathrm{F}$ & $2 / 5.6$ & $\begin{array}{l}\text { Edema, irritability, arthralgia/ } \\
\text { arthritis }\end{array}$ & 7 & Exanthema begin on the MMII & & 10 \\
\hline $10 / \mathrm{F}$ & $1 / 3.9$ & Cyanosis of hands and feet & 1 & $\begin{array}{l}\text { Diffuse exanthema, sparing the face, } \\
\text { hyperpigmentation, paleness }\end{array}$ & No & 13 \\
\hline $11 / \mathrm{M}$ & $2 / 4.4$ & Irritability, digestive bleeding & 2 & $\begin{array}{l}\text { Exanthema begin on the MMII, } \\
\text { vesicles, bullous ( } 4 \text { days), } \\
\text { hyperpigmentation, peeling }\end{array}$ & No & 11 \\
\hline $12 / \mathrm{M}$ & $1 / 5.6$ & Irritability & 13 & $\begin{array}{l}\text { Diffuse exanthema, vesicles, bullous ( } 5 \\
\text { days), peeling }\end{array}$ & No & 18 \\
\hline $13 / \mathrm{M}$ & $4 / 8.1$ & $\begin{array}{l}\text { Vomiting, irritability, arthralgias/ } \\
\text { arthritis }\end{array}$ & 4 & Exanthema & No & 5 \\
\hline $14 / \mathrm{M}$ & $15 / 10$ & Vomiting, arthralgia/arthritis & 16 & Exanthema & Sickle cell anemia & 8 \\
\hline
\end{tabular}

a Gender: $\mathrm{M}=$ male; $\mathrm{F}=$ female; $\mathrm{b} \mathrm{m}=$ months; $\mathrm{c} \mathrm{MMII}=$ lower limbs. 
Figure 1

Cutaneous manifestations of infants with chikungunya.
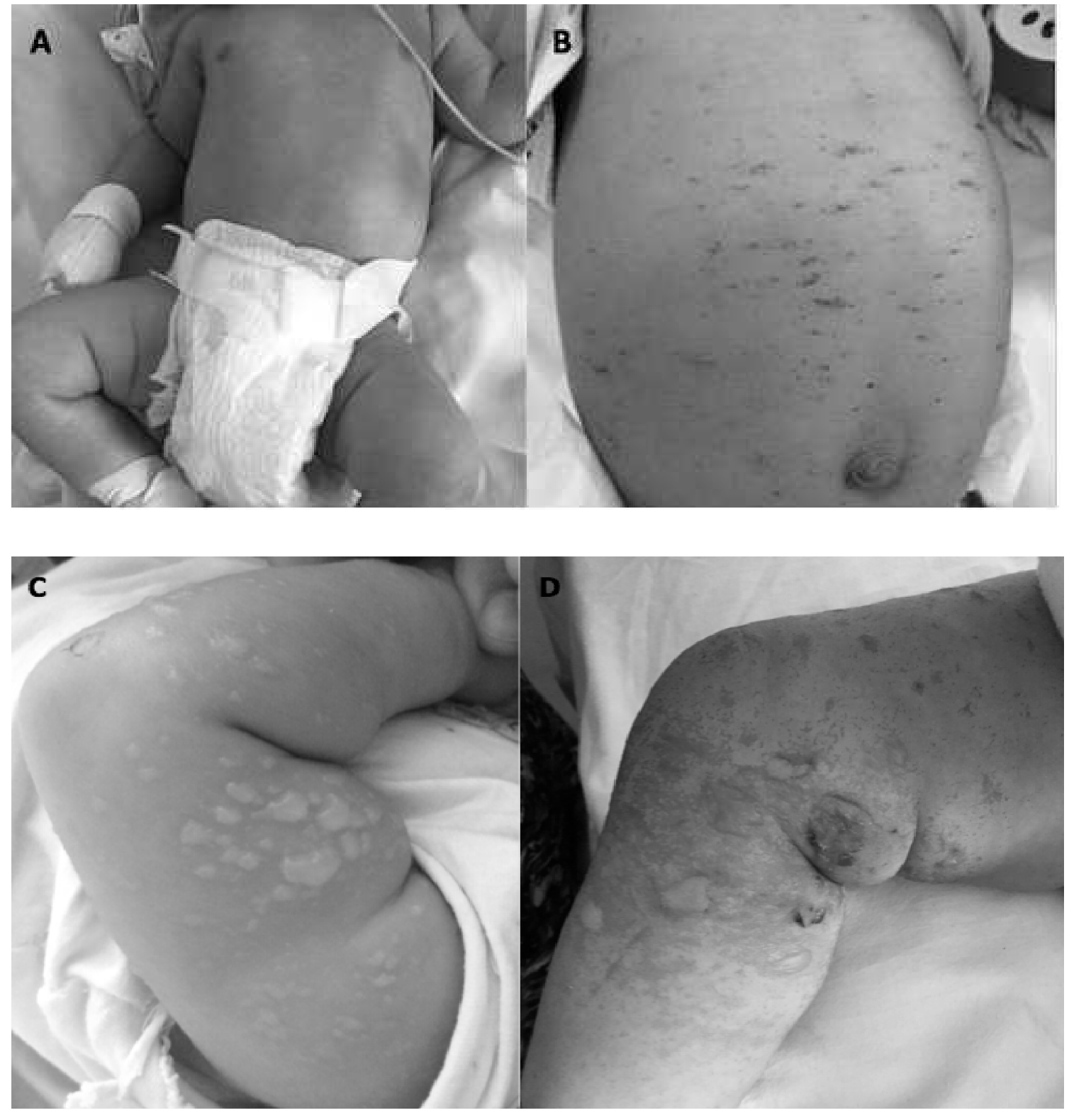

A) Typical macular diffuse of exanthema erythematosus; B) Hyperpigmentation; C) Vesicles and bullous; D) Exulceration. Source: Bank of images of hospitalized children at IMIP with the infection of CHIKV. 
Table 2

\begin{tabular}{|c|c|c|c|c|c|c|c|c|}
\hline $\begin{array}{l}\text { Patient } \\
\mathbf{N}^{\circ}\end{array}$ & $\begin{array}{l}\mathrm{Hba} \\
(\mathrm{g} / \mathrm{dL})\end{array}$ & $\begin{array}{l}\text { Total } \\
\text { leukocytes }\left(\mathrm{mm}^{3}\right)\end{array}$ & $\begin{array}{l}\text { Segmented/ } \\
\text { Sticks/ goal (\%) }\end{array}$ & $\begin{array}{l}\text { Typical/atypical } \\
\text { lymphocytes }\end{array}$ & $\begin{array}{l}\text { Platelets } \\
\left(\mathrm{mm}^{3}\right)\end{array}$ & LCRb & $\begin{array}{c}\text { LCR Cellularity }\left(\mathrm{mm}^{3}\right) / \\
\text { neutrophils/lymphocytes (\%) }\end{array}$ & $\begin{array}{c}\text { Other relevant } \\
\text { testsc }\end{array}$ \\
\hline 1 & 11.0 & 12.300 & $69.3 / 0$ & $17.4 / 0$ & 237.000 & Sim & 1 & - \\
\hline 2 & 8.8 & 6.100 & $29 / 7$ & $379 / 15$ & 158.000 & Não & - & - \\
\hline 3 & 10.8 & 14.200 & $71.1 / 0$ & $20.6 / 7$ & 399.000 & Não & - & $A S T=52 ; A L T=19$ \\
\hline 4 & 11.6 & 10.000 & $53 / 25$ & $20 / 1$ & 136.000 & Sim & $100 ; 0 / 100$ & - \\
\hline 5 & 8.3 & 8.400 & $69 / 0$ & $24 / 0$ & 443.00 & Não & - & - \\
\hline 6 & 6.8 & 7.600 & $25 / 17$ & $47 / 0$ & 141.000 & Sim & $50 ; 49 / 51$ & $\mathrm{AST}=230 ; \mathrm{ALT}=49$ \\
\hline 7 & 11.1 & 7.600 & $63 / 0$ & $27 / 0$ & 268.000 & Não & - & - \\
\hline 8 & 8.0 & 3.100 & $48 / 13$ & $33 / 0$ & 215.000 & Não & - & - \\
\hline 9 & 6.3 & 20.300 & $73 / 15$ & $11 / 0$ & 246.000 & Não & - & - \\
\hline 10 & 12.2 & 8.500 & $51 / 13$ & $24 / 0$ & 289.000 & Sim & $50 ; 65 / 35$ & - \\
\hline 11 & 6.8 & 6.500 & $33 / 4$ & $62 / 0$ & 200.000 & Não & - & $\begin{aligned} A S T & =428 ; A L T=83 \\
\text { INR } & =1,66 ; A E=45 \%\end{aligned}$ \\
\hline 12 & 8.3 & 7.900 & $49 / 11$ & $32 / 1$ & 210.000 & Não & - & $\begin{array}{c}\mathrm{AST}=450 ; \mathrm{ALT}=160 \\
\mathrm{CPK}>2.670 \mathrm{U} / \mathrm{L}\end{array}$ \\
\hline 13 & 8.6 & 2.600 & $48.5 / 0$ & $41.5 / 0$ & 259.000 & Não & - & - \\
\hline 14 & 10.6 & 11.700 & $55.6 / 0$ & $34.6 / 0$ & 454.000 & Não & - & - \\
\hline
\end{tabular}

$\mathrm{a} \mathrm{Hb}=$ hemoglobin; $\mathrm{b} \mathrm{LCR}=$ cerebrospinal fluid; $\mathrm{c}$ AST $=$ aspartate aminotransferase; $\mathrm{ALT}=$ alanine aminotransferase; $\mathrm{CPK}=$ creatina phosphokinase . 
Therapeutic characteristics of 14 infants with chikungunya, $11 / 30 / 2015$ to $01 / 17 / 2016$.

\begin{tabular}{|c|c|c|c|c|c|c|}
\hline $\begin{array}{l}\text { Patient } \\
\text { Number }\end{array}$ & Venous access & Volume expansion & $\begin{array}{l}\text { Antibiotic therapy/ which/ } \\
\text { Dose (mg/kg/day)/ Duration }\end{array}$ & Analgesia/drugs & Skin Care & $\begin{array}{l}\text { Blood transfusion/ } \\
\text { which/dose }\end{array}$ \\
\hline 1 & Peripheral & No & No & No & Vegetable oil with $\mathrm{TCM}{ }^{\mathrm{b}}$ & No \\
\hline 2 & Peripheral & No & No & Yes, dipyrone & Silver Sulfadiazine & No \\
\hline 3 & Peripheral & No & Cephalothin/cephalexin $(100), 10$ days & No & Vegetable oil with TCM & No \\
\hline 4 & Peripheral & No & $\begin{array}{c}\text { Cephalothin/cephalexin (100), } 10 \text { days } \\
\text { Gentamicin (5), } 2 \text { days }\end{array}$ & No & Silver Sulfadiazine & No \\
\hline 5 & Peripheral & No & Ceftriaxone $(100), 6$ days & Yes, codeine & Vegetable oil with TCM & No \\
\hline 6 & Peripheral & No & $\begin{array}{l}\text { Oxacillin (200), } 10 \text { days } \\
\text { Gentamicin (5), } 10 \text { days }\end{array}$ & No & Vegetable oil with TCM & No \\
\hline 7 & Peripheral & No & No & No & Vegetable oil with TCM & No \\
\hline 8 & Peripheral & $\mathrm{SF} 0.9 \% 50 \mathrm{ml} / \mathrm{kg}$ & $\begin{array}{l}\text { Cephalothin (100), } 10 \text { days } \\
\text { Gentamicin (5) } 10 \text { Days }\end{array}$ & No & Vegetable oil with TCM & No \\
\hline 9 & Peripheral and Central & $\mathrm{SF} 0.9 \% 40 \mathrm{ml} / \mathrm{kg}$ & Oxacillin (200), 10 days & No & Vegetable oil with TCM & $\begin{array}{c}\text { Red blood cell } \\
\text { concentrated } 10 \mathrm{ml} / \mathrm{kg}\end{array}$ \\
\hline 10 & Peripheral & No & $\begin{array}{l}\text { Ampicillin (200), } 10 \text { days } \\
\text { Gentamicin (5), } 10 \text { days }\end{array}$ & No & Vegetable oil with TCM & No \\
\hline 11 & Peripheral and Central & No & $\begin{array}{l}\text { Oxacillin/cephalexin (200), } 10 \text { days } \\
\text { Gentamicin (5), } 3 \text { days }\end{array}$ & Yes, tramadol & Silver Sulfadiazine & $\begin{array}{l}\text { Red blood cell } \\
\text { concentrated } 10 \mathrm{ml} / \mathrm{kg}\end{array}$ \\
\hline 12 & Peripheral and Central & $\mathrm{SF} 0.9 \% 20 \mathrm{ml} / \mathrm{kg}$ & $\begin{array}{l}\text { Oxacillin (200), } 10 \text { days } \\
\text { Gentamicin (5), } 5 \text { days }\end{array}$ & No & Silver Sulfadiazine & No \\
\hline 13 & Peripheral & No & No & No & Vegetable oil with TCM & No \\
\hline 14 & Peripheral & $\mathrm{SF} 0.9 \% 50 \mathrm{ml} / \mathrm{kg}$ & No & No & Vegetable oil with TCM & No \\
\hline
\end{tabular}

a $\mathrm{SF}=$ saline; $\mathrm{b} \mathrm{TCM}=$ medium-chain triglycerides. 
festations in 52 children, 22 infants reported no description of ulcers. 12 In contrast to these findings, a retrospective study in Colombia, in December, 2014 evaluated 11 cases (neonates and infants) with atypical mucocutaneous manifestations and observed the presence of multiple round and oval ulcers in the perineal area, genital and in the lower extremities in $78 \%$ of the cases, this occurs after three to four days of the beginning of a fever. ${ }^{13}$

Other relevant findings and in agreement with the present study were the high frequency of irritability and low manifestations rheumatological. 8,14 A study in India, in the months of May to July 2007, 56 children under one year of age were evaluated and observed a high frequency of peripheral cyanosis without hemodynamic alteration of $75 \%$, irritability or excessive crying $26.8 \%$, lethargy $21.4 \%$ and the absence of articular manifestations. 15

As for laboratorial changes, there was a verification on the high frequency of anemia, even by using different cut-off points. A study conducted on the island of La Réunion also verified the presence of anemia in $46.1 \%$ of the cases $(\mathrm{Hb}<9.5 \%) .{ }^{11} \mathrm{It}$ is noteworthy that infants less than three months old may have overlapping physiological anemia, therefore not exclusively secondary to the infection. 20 By disagreeing of our data, studies report lymphopenia, neutropenia and thrombocytopenia. 11,12,14 Relevant data not described in other studies was the presence of more than $10 \%$ of immature neutrophils in the leukograms of $43 \%$ of the cases. Less common abnormalities, as an increase of cellularity of the LCR, high aminotransferases, high CPK and leukopenia also were described in other studies. 8,14

No specific treatment is available for the infection by CHIKV. The treatment is supportive and the attention should be given to adequate hydration, analgesia, the use of antipyretic and care with skin lesions. Moreover, currently the most effective way to control the disease is by combating the vector. 8,20 Other studies also reported the need of therapeutic support. Robin et al. ${ }^{11}$ observed that some patients also needed central venous access, volume expansion and blood transfusion, however, there is no report on antibiotic therapy. A study in India draws attention to the indiscriminate use of antibiotic therapy, corticosteroids and non steroids anti-inflammatory drugs, especially aspirin. ${ }^{15}$ The excessive use of antibiotics in this present study might be attributed to the fact that these cases were first observed in infants in Pernambuco, on the occurrence of bastonetose in these patients and especially treating young infants. Additionally, the two patients older than three months received antibiotic therapy, one was diagnosed with sickle cell anemia (Level 5) and the other presented secondary infection (Level 3).

The low use of analgesia in this case series is also emphasized. Most of the infants showed a lot of irritability, which could be attributed to the pain due to cutaneous lesions and/or osteoarticular involvement. Therefore, it is recommended that a systematic monitoring and a period of presenting pain with the use of specific schedules 22 and to institute clinical protocol to control infants pain in the ward environment.

Chikungunya infection is a self limiting disease and with low lethality. We did not observe the occurrence of death similar to the findings in other studies. 11,15

Despite the importance of this study, it should emphasize that this is a retrospective study, some information could not be described or detailed for the lack of information in the medical records.

This present study corroborates to previous studies on the multisystemic involvement of chikungunya infection in infants. This arbovirus should be considered in the differential diagnosis of feverish infants with cutaneous manifestations, especially bullous lesions in regions where the virus circulation is. In infants with infection by CHIKV, other clinical findings commonly observed irritability, arthralgias/arthritis and vomiting, while the laboratorial observed anemia, increased immature neutrophils, the aminotransferases and cellularity in LCR. The treatment remains supportive, but the attention should be given to hydration, analgesia, care of skin lesions and the rational use of antibiotic therapy.

\section{References}

1. Rougeron V, Sam I, Caron M, Nkoghe D, Leroy E, Roques P. Chikungunya, a paradigm of neglected tropical disease that emerged to be a new health global risk. J Clin Virol. 2015; 64: 144-52.

2. Burt FJ, Rolph MS, Rulli NE, Mahalingam S, Heise MT Chikungunya: a re-emerging virus. Lancet. 2012; 379: 66271.
3. Fischer M, Staples JE, Arboviral Diseases Branch, National Center for Emerging and Zoonotic Infectious Diseases, CDC. Notes from the field: chikungunya virus spreads in the Americas - Caribbean and South America, 2013-2014. MMWR Morb Mortal Wkly Rep. 2014; 63: 500-1. 
4. Nunes MR, Faria NR, Vasconcelos JM, Golding N, Kraemer MU, Oliveira MU, Azevedo Rdo S, Silva DE, Silva EV, Silva SP, Carvalho VL, Coelho GE, Cruz AC, Rodrigues SG, Vianez JL Jr, Nunes BT, Cardoso JF, Tesh RB, Hay SI, Pybus OG, Vasconcelos PF. Emergence and potential for spread of Chikungunya virus in Brazil. BMC Med. 2015; 13: 102.

5. Boletim Epidemiológico, Secretaria de Vigilância em Saúde, Ministério da Saúde. 2016. [acesso em 13 junho 2016]. Disponível em: <http://portalsaude.saude.gov.br/ images/pdf/2016/maio/17/2016-016---Dengue-SE16publica----o.pdf $>$

6. Pan American Health Organization. Preparedness and Response for Chikungunya Virus: Introduction in the Americas; 2011.

7. Ernould S, Walters H, Alessandri JL, et al. Chikungunya in paediatrics: epidemic of 2005-2006 in Saint-Denis, Reunion Island. Arch Pediatr. 2008; 15: 253-62.

8. Ritz N, Hufnagel M, Gérardin P. Chikungunya in Children. Pediatr Infect Dis J. 2015; 34: 789-91.

9. WHO (World Health Organization). Iron deficiency anemia: assessment, prevention and control. A guide for programme managers. Geneve, 2001.

10. Goldstein B, Giroir B, Randolph A and the Members of the International Consensus

Conference on Pediatric Sepsis. International pediatric sepsis consensus conference:

Definitions for sepsis and organ dysfunction in pediatrics. Pediatr Crit Care Med. 2005; 6: 2-8.

11. Robin S, Ramful D, Zettor J, Benhamou L, Jaffar-Bandajee $\mathrm{MC}$, Rivière JP, Marichy J, Ezzedine K,Alessandri JL. Severe bullous skin lesions associated with Chikungunya virus infection in small infants. Eur J Pediatr. 2010; 169: 67-72.

12. Seetharam KA, Sridevi K, Vidyasagar P. Cutaneous Manifestations of Chikungunya Fever. Indian Pediatr. 2012; 49: 51-3.

Received on June 21, 2016

Final version presented on August 2, 2016

Approved on September 8, 2016
13. Muñoz CM, Castillo JO, Salas D, Valderrama MA, Rangel CT, Vargas HP, et al. Fiebre por virus chikungunya en neonatos y lactantes con manifestaciones mucocutáneas atípicas, municipios de Cúcuta, Los Patios y Villa del Rosario, Norte de Santander, Colombia, 2014. Biomédica. 2016; 36: 1-35.

14. Thiberville S-D, Moyen N, Dupuis-Maguiraga L, Nougairede A, Gould EA, Roques P, et al. Chikungunya fever: Epidemiology, clinical syndrome, pathogenesis and therapy. Antiviral Res. 2013; 99: 345-70.

15. Valamparampil JJ, Chirakkarot S, Letha S, Jayakumar C, Gopinathan KM. Clinical profile of chikungunya in infants. Indian J Pediatr. 2009; 76: 151-5.

16. Robin S, Ramful D, Le Seach' F, Jaffar-Bandjee MC, Rigou G, Alessandri JL. Neurologic manifestations of pediatric chikungunya infection. J Child Neurol. 2008; 23: 1028-35.

17. Inamadar AC, Palit A, Sampagavi VV, Raghunath S, Deshmukh NS. Cutaneous manifestations of chikungunya fever: observations made during a recent outbreak in south India. Int J Dermatol. 2008; 47: 154-9.

18. Genderen FT, Krishnadath I, Sno R, Grunberg MG, Zijlmans W, Adhin MR. First chikungunya outbreak in Suriname; clinical and epidemiological features. Plos Negl Trop Dis. 2016; 10: e0004625.

19. Raghavendhar BS, Ray P, Ratagiri VH, Sharma BS, Kabra SK, Lodha R. Evaluation of chikungunya virus infection in children from India during 2009-2010: a cross sectional observational study. J Med Virol. 2016; 88: 923-30.

20. Widness JA. Pathophysiology of anemia during the neonatal period, including anemia of prematurity. Neoreviews. 2008; 9: e520.

21. Azevedo RSSO, Vasconcelos CS, Costa PF. Chikungunya risk for Brazil. Rev Saúde Pública. 2015; 49: 58.

22. Stinson JN, Kavanagh T, Yamada J, Gill N, Stevens B Systematic review of the psychometric properties, interpretability and feasibility of self-report pain intensity measures for use in clinical trials in children and adolescents. Pain. 2006; 125: 143-57. 